\title{
TEMA UTAMA TEOLOGI TITUS
}

\author{
Dr. Daniel Tumbel \\ Sekolah Tinggi Teologi Injili Indonesia Surabaya \\ E-mail:danieltumbel@sttii-surabaya.ac.id
}

\begin{abstract}
The New Testament Epistle of Titus was written by Paul. He writes this letter to instruct Titus in regard to overseeing the believers in Crete. There are lots of things Titus must know and do to help these believers. The people in Crete are fairly new believers and they need to be organized into local churches. Titus' responsibility is to appoint leadership in the churches and to ground the believers in sound doctrine. Spiritually qualified elders and doctrinally grounded believers will greatly promote spiritual unity in the local churches.

The biblical teaching would provide the necessary components for biblical conflict resolution in the future. Paul writes Titus as his representative in Crete to aid the churches on a prophylactic way against Jewish false teachers by appointing those in leadership who are able tio manage God's household well and stand against the false teachers, and by exhorting all believers to excel in good works so tha they might reach those outside of the church with the gospel.

Keywords: New Testament, Epistle of Titus, Jewish,Biblical
\end{abstract}

\section{PENDAHULUAN}

Surat Titus bersama dengan surat 1 dan 2 Timotius telah lama dikenal sebagai Surat-surat Penggembalaan. Istilah ini pertama dipakai oleh D.N. Berdot tahun 1703 dan dipopulerkan oleh Paul Anton tahun 1726. ${ }^{1}$ Sekalipun surat-surat tersebut tidak sepenuhnya dapat dijadikan penuntun bagi teologi pastoral, namun nama tersebut memang praktis untuk mengkhususkan ketiga surat tersebut. "Surat surat pastoral" (1 dan 2 Timotius dan Titus) sangat berbeda baik dari segi gaya bahasa maupun isi dari surat-surat Paulus lainnya. Mereka ditulis dengan maksud memberi nasehat kepada pada pemimpin jemaat mula-mula. Baik Timotius dan Titus disebut di tempat lain sebagai teman-teman sekerja Paulus, walaupun mereka juga bekerja secara tersendiri: Titus di Kreta, dan Timotius di Efesus.Surat-surat pastoral ini adalah surat-surat Paulus yang paling banyak diserang oleh dunia teologia modern dewasa ini meskipun di masa awal gereja keotentikan surat-surat tersebut tidak diragukan lagi.

\section{Keotentikan Surat Titus}

Pandangan Tradisional terhadap keotentikan surat Titus menyajikan dua bukti yang akurat yaitu bukti dari dalam surat itu sendiri (internal) dan bukti-bukti dari luar surat (eksternal) yang meyakinkan bahwa surat Titus adalah asli ditulis oleh Paulus sendiri. Bukti internal telah jelas terlihat dalam bagian awal surat Titus ketika Paulus menuliskan salam yang berbunyi: "Dari Paulus, hamba

\footnotetext{
${ }^{1}$ Donald Guthrie, Pengantar Perjanjian Baru Jilid 2

(Surabaya: Penerbit Momentum, 2009), p. 191.
}

Allah dan rasul Yesus Kristus untuk memelihara iman orang-orang pilihan Allah dan pengetahuan akan kebenaran seperti yang nampak dalam ibadah kita," (Tit. $1: 1)$.

Mereka yang menyangkal kepenulisan Paulus menganggap Surat-surat Penggembalaan bernatur pseudonimus $^{2}$. Bagi banyak teolog, hal ini bukan masalah karena mereka menganggap praktik ini sudah umum di dunia sekuler dan diterima oleh jemaat. Tetapi bukti bagi surat pseudonimus tidak cukup berbobot. Sebagian besar bukti berupa kutipan dalam tulisan lain yang membahas gaya sastra. Selain beberapa surat Paulus di Perjanjian Baru yang dituduh palsu, hanya ada dua surat pseudonimus yang memakai nama Paulus, yaitu: Surat Laodikia, yang jelas palsu karena tidak memiliki kesaksian Yunani awal dan tidak muncul di gereja Latin sampai abad keempat, dan surat 3 Korintus, yang sempat beredar secara terpisah di gereja Siria dan yang bahkan sempat dianggap sebagai Kitab suci di sana, telah ditemukan berasal dari Kisah Paulus, yang mereproduksi catatan Tertulian. ${ }^{3}$ Semua bukti ini tidak memadai untuk mendukung praktik pseudonimus di Kekristenan awal.

Bukti eksternal memberikan kesaksian yang cukup besat bahwa Surat Titus ditulis oleh Paulus sendiri. Dukungan bukti eksternal sama banyaknya dengan dukungan yang didapat oleh surat-surat Paulus lainnya, kecuali 1 Korintus dan Roma. Surat Titus dan suratsurat Penggembalaan lainnya memiliki banyak keserupaan bahasa dengan surat Klemens kepada jemaat Korintus dan hal ini tampaknya menjadi bukti kuat bagi keasliannya. Tetapi bukti ini ditafsirkan secara berbeda oleh sebagian teolog. Menurut mereka, Surat-surat

\footnotetext{
${ }^{2}$ Pseudonimus adalah surat-surat yang memakai identitas penulis palsu atau samaran.

${ }^{3}$ Donald Guthrie, p. 192.
} 
penggembalaan (termasuk di dalamnya surat Titus) harus ditulis di abad kedua, karena 1 Klemens ex hypothesi harus mendahului dan dipakai oleh penulis Surat-surat Penggembalaan. ${ }^{4} \quad$ Teolog lain tidak menganggap keserupaan ini cukup dekat untuk membuktikan suatu kebergantungan. ${ }^{5}$ Ada petunjuk bahwa Surat-surat Penggembalaan telah dikenal dan dipakai oleh Polikarpus, ${ }^{6}$ Justin Martyr, Herakleon, dan lain-lain, dan pada waktu Irenaeus, ketiganya telah mutlak dianggap ditulis oleh Paulus. ${ }^{7}$ Kanon Muratorian memasukkan surat-surat ini ke dalam corpus surat Paulus. ${ }^{8}$ Semua bukti ini memberikan dukungan yang sangat besar dan penting bahwa Paulus lah penulis dari Surat-surat Penggembalaannya, dimana di dalamnya termasuk surat Titus.

\section{Latar Belakang Penulisan}

Seperti halnya surat-surat pastoral lainnya, yaitu 1 dan 2 Timotius, surat Titus tidak ditulis untuk sidang jemaat secara umum, melainkan surat-surat ini dituliskan

\footnotetext{
${ }^{4}$ B.H. Streeter, The Primitive Church (1929) p, 153, dan P.N. Harrison, The Problem of the Pastoral Epistles (1921) p. 177. Bagi pendapat yang berbeda, bandingkan pula tulisan Sir R. Falconer, Pastoral Epistles (1937), p. 5.

${ }^{5}$ Bandingkan dengan Oxford Society of Historical Theology. The New Testament in the Apostolic Fathers (1905), p. 37.

${ }^{6}$ A. E. Barnett, Paul Becomes a Literary Influence (1941), p. 182-184, melawan pandangan bahwa Surat-surat penggembalaan masuk dalam corpus surat Paulus yang Polikarpus miliki, dengan alas an yang sepenuhnya subjektif. Setelah meletakkan surat-surat ini di dalam periode setelah Polikarpus, ia menjelaskan kutipan yang ada sebagai pemakaiana paraenesis umum. Dengan ini, bukti eksternal apapun ditiadakan demi kepentingan teori yang dipresuposisikan. Polikarpus jelas tahu dan memakai suratsurat ini (bandingkan A. Harnack, Die Briefsammlung des Apostels Paulus, 1926, p. 72). Bagi relasi antara Polikarpus dan Surat-surat Penggembalaan, bandingkan tulisan H. von Campenhausen. "Polykarp und die Pastoralbriefe," Sitzungsberichte der Heidelberger Akademic der Wissenchaften, philosophisch-historische Klasse (1951). ${ }^{7}$ Bandingkan J. H. Bernard, The Pastoral Epistles (1899), p. xiv-xv; dan J.D. James, The Genuineness and Authorship of the Pastoral Epistles (1906), p. 5-24, bagi uraian bukti eksternal secara penuh. Dibelius, The Pastoral Epistles (H. conzelmann, ed.), (Herm)(1972), p. 2, menyangkal rujukan Polikarpus tetapi Jeremias, Die Briefe an Timotheus, 1807, p. 16-19) menerima hal ini. Perlu diperhatikan bahwa F. Schleiermarcher, yang menyangkal keaslian 1 Timotius saja, menegaskan bahwa di mana kecurigaan kritis ditegakkan, kesaksian Kuni sulit dipertahankan (F. Schleiermarcher, Uber den sogenannten ersten Brief des Paulus an den Timotheus, 1807, p. 16-19).

${ }^{8}$ Kanon Muratorian menyebut ketiga surat ini, bersama Filemon, sebagai surat yang berguna bagi pemakaian gerejawi. Mereka disebut setelah surat-surat yang dikirim bagi jemaat tetapi tidak ada petunjukbahwa surat-surat ini lebih rendah. Harus pula dicatat bahwa dalam Gospel of Truth, sebuah karya Gnostik, tidak ada rujukan yang jelas kepada surat-surat ini, tetapi hal ini bisa dipahami Karen Gnostik umunya menolak surat-surat ini.
}

kepada dua orang yang sedang bekerja di antara kelompok-kelompok orang-orang percaya mula-mula. Surat-surat ini bersifat pribadi dan ditujukan kepada pribadi-pribadi khusus, yaitu Timotius muda dan Titus. Timotius melayani di Efesus sementara Titus di Kreta.

Penerima surat Titus seperti dituliskan dalam pembuka surat adalah Titus sendiri (Tit. 1:4). Ia disebut sebagai "anakku yang sah menurut iman kita bersama." Ini menjelaskan bahwa Titus adalah anak rohani dari Paulus dan bahwa Paulus sendiri yang memenangkan dia di dalam iman. Titus rupanya telah ditinggalkan Paulus di Kreta dengan maksud supaya Titus mengatur apa yang masih perlu diatur dan supaya ia menetapkan penatuapenatua di setiap kota, seperti yang telah dipesankan Paulus kepadanya.

Nama Titus tidak disebut dalam Kisah Para Rasul tetapi Titus adalah rekan Paulus yang sangat dipercayai. Namanya muncul pertama kalinya saat timbul silang pendapat perihal non-Yahudi, tatkala ia menemani Paulus dan Barnabas ke Yerusalem (Gal. 2:1). Ia sendiri merupakan persoalan karena bukan Yahudi, tapi nampaknya ia tidak dipaksa supaya disunat (Gal. 2:3). Mungkin Titus menemani Paulus pada perjalanan yang kemudian, tapi apa peranannya baru dapat diketahui setelah jemaat Korintus berada dalam keadaan gawat. Jelas ia bertindak sebagai wakil Paulus di Korintus selama tahun menjelang penulisan 2 Korintus, dengan tugas khusus mengatur pengumpulan persembahan untuk jemaat di Yerusalem. Tugas itu tidak tuntas, sebab Paulus mendesak Titus segera kembali ke Korintus untuk pelayanan kasih (2 Kor. 8:6).

Tugas lain yang diemban oleh Titus ialah mengendorkan keadaan tegang yang timbul antara Paulus dan orang-orang Korintus. Tugas ini jelas menuntut seorang bijaksana berjiwa luhur dan kuat. Kelihatannya Titus berwatak lebih kuat daripada Timotius (bandingkan 1 Kor. 16:10; 2 Kor. 7:15) dan sanggup sebagai pengatur (pemegang tata usaha). Membandingkan 2 Korintus 2 dengan 2 Korintus 7 akan didapatkan kesan bahwa Titus membawa seepucuk surat dari Paulus kepada orang Korintus, yang sejak itu hilang lenyap ("surat yang keras itu"). Dalam surat itu Paulus dengan kesedihan hati yang sangat menempelak mereka karena sikap mereka yang angkuh. Akhirnya Titus bergabung lagi dengan Paulus di Makedonia (2 Kor. 7:6) dengan membawa kabar baik. Sebagai buahnya 2 Korintus ditulis dan dibawa dengan senang hati oleh Titus, yang nampaknya sangat prihatin akan keadaan masyarakat Kristen di Korintus (2 Kor. 8:6). Paulus menyebut Titus sebagai 'temanku yang bekerja bersamasama dengan aku untuk kamu' (2 Kor. 8:23), seorang yang tidak akan menipu orang-orang yang dipercayakan pada pembinaannya (2 Kor. 12:18). ${ }^{9}$

\footnotetext{
${ }^{9}$ J. D. Douglas, Ensiklopedi Alkitab Masa Kini Jilid II (Jakarta: Yayasan Komunikasi Bina Kasih/OMF, 2004), p. 485.
} 
Dari surat yang dialamatkan kepada Titus, bisa diyakini bahwa ia menemani Paulus ke Kreta sesudah rasul itu dilepaskan dari penjara Roma. Kemudian ia ditinggalkan di sana untuk menata dan memperkokoh pekerjaan di sana (Tit. 1:5). Sesudah itu Titus disuruh supaya bergabung dengan Paulus di Nikopolis jika artemas atau Tikhikus sudah diangkat untuk menggantikan dia (Tit. 3:12). Mungkin ia mendapatkan tugas baru untuk memberitakan Injil ke Damlatia, karena ia masih menjalankan pekerjaan itu saat Paulus menulis 2 Timotius (2 Tim. 4:10). Tapi tradisi di kemudian hari mengatakan ia kembali ke Kreta, dan bahwa ia menjadi uskup di sana sampai hari tuanya. ${ }^{10}$ Ada kemungkinan bahwa ia kakak-adik dengan Lukas ${ }^{11}$ (yang mungkin bisa menjelaskan mengapa nama Titus tidak dimasukkan dalam kitab Kisah Para Rasul).

\section{Tujuan Penulisan}

Selesai mengunjungi jemaat-jemaat Makedonia, Paulus bertolak lagi ke Asia Kecil dengan mengajak Titus. Jalan yang ia tempuh adalah melewati Troas (2 Tim. 4:13) ke Efesus, di mana ia menengok Timotius sesuai dengan janjinya (1 Tim. 3:14). Kemudian ia pergi ke Miletus (2 Tim. 4:20) dan dari sana ke pulau Kreta. Di Kreta, Paulus melakukan kegiatan untuk beberapa waktu lamanya, kemudian meninggalkan Titus di pulau tersebut (Tit. 1:5) ${ }^{12}$ dengan tugas membina jemaat-jemaat yang baru. Paulus sendiri meneruskan perjalanannya ke Akhaia lewat Korintus (2 Tim. 4:20). Ia kemudian bermukim di Nikopolis (Tit. 3:12) ${ }^{13}$. Dari sini ia menulis surat kepada Titus di Kreta (sekitar tahun $64 \mathrm{M})^{14}$ dan

\footnotetext{
${ }^{10}$ Eusebius, Ecclesiastical History, 3.4.6

${ }^{11}$ Lihat W.M. Ramsay, St. Paul The Traveller and Roman Citizen, (1920), p. 390

${ }^{12}$ Dari ayat ini telah dapat disimpulkan bahwa Paulus pernah mengunjungi Kreta, karena rupanya di situ juga ada kelompokkelompok orang Kristen.

${ }^{13}$ Kunjungan ini dan kunungan Paulus ke daerah-daerah sekitar Laut Adriatik menyimpang dari siasat yang dilaksanakannya sampai saat itu, yakni menanamkan jemaat-jemaat dalam kotakota yang penting. Walalupun demikian perubahan rencana yang strategis pada pola daerah territorial yang lebih luas itu cocok dengan kemungkinan kunjungannya ke Spanyol pada masa yang sama (Roma 15:24, 28). Kreta, dalmatia, Spanyol meliputi daerah Lautan Tengah bagian tengah dan barat dalam sebuah segitiga. II Timotius $(1: 16 ; 4: 13 ; 4: 20)$ menyebut nama tempat-tempat yang menunjukkan perjalanan-perjalanan lain. Pendeknya, bukti sana bukti di sana-sini menunjukkan tiga atau empat tahun kegiatan yang bersemangat dalam penginjilan, atau mungkin kegiatan dalam mengatur organisasi karena mengingat ancaman yang bertambah besar. Mungkin Paulus ditahan di Troas pada tahun 66 atau $67 \mathrm{M}$. Ia meninggalakan jubah dan catatan-catatan berharganya, mungkin untuk menghindari supaya tuan rumahnya tidak ikut terlibat, atau mungkin sebab ia dibawa pergi dengan tergesa-gesa.

${ }^{14}$ Paulus dibebaskan dari tahanan rumah di Rona tetapi sebelum penganiayaan oleh Nero dalam tahun 64. ia menulis surat yang pertama kepada Timotius dan kepada Titus segera
}

meminta kepadanya untuk bergabung di Nikopolis dan melanjutkan pekerjaan rasul Paulus di daerah itu. Paulus kemudian bertolak ke Roma dengan maksud untuk melaksanakan rencana Pekabaran Injil ke Spanyol yang sekian lamanya tertunda. Agaknya Titus berhasil di dalam usaha pekabaran Injil di sekitar Nikopolis, sebab ia memperluas kegiatannya ke Utara, ke wilayah Dalmatia di Yunani Barat (2 Tim. 4:10).

Adapun tujuan Paulus meninggalkan Titus di Pulau Kreta dengan sangat jelas dituliskan Paulus dalam suratnya, yaitu: supaya Titus mengatur apa yang masih perlu diatur, dan selanjutnya supaya Titus menetapkan penatua-penatua di setiap kota, seperti yang telah dipesankan Paulus kepadanya. Paulus dalam suratnya mendesak Titus supaya ia menggunakan kekuasaannya menetapkan pejabat-pejabat yang layak, mengatasi perlawanan dan dalam mengajarkan ajaran yang murni.

Nampaknya Paulus menugaskan Titus supaya dengan cepat mengatur apa yang belum teratur dalam jemaat Kreta (1:3). Tugas ini harus diselesaikan dengan cepat sampai Paulus mengirim Artemas atau Tikhikus. Tugas ini adalah tugas yang berhubungan dengan masalah praktis. ${ }^{15}$ Namun dari keseluruhan surat ini menunjukkan bahwa surat ini adalah perintah kepada Titus untuk melindungi jemaat melawan guru-guru palsu Yahudi dengan cara menunjuk penatua-penatua yang mampu mengatur rumah tangga Allah untuk berdiri teguh melawan guru palsu tersebut, serta menasihatkan jemaat supaya berbuat baik supaya dengan demikian mereka bisa menarik orang luar ${ }^{16}$.

\section{TEMA UTAMA}

Sama seperti surat 1 dan 2 Timotius, surat Titus berisikan petunjuk-petunjuk cara bagaimana menata hidup jemaat-jemaat dan menanggulangi ajaran-ajaran sesat. Ajaran sesat yang ada di Kreta mempunyai banyak persamaan dengan yang ada di Efesus (1 dan 2 Timotius). Cara menanggulangi ajaran-ajaran sesat itu adalah dengan mengangkat para penatua dan mengajarkan serta mempraktekkan ajaran-ajaran yang sehat atau kebenaran yang sesungguhnya. Jemaat perlu diajarkan ajaran sehat dan kemudian menerapkan kebenaran atau ajaran tersebut dalam kehidupan mereka.

\section{Beritakanlah Apa yang Sesuai dengan Ajaran yang Sehat}

sesudah pembebasannnya, barangkali sebelum tahun 64 tetapi bisa juga sesudahnya. E.M. Blaiklock, Surat-surat Penggembalaan (Buku Pedoman untuk Mempelajari Suratsurat Kirimiman I dan II Timotius dan Titus_ (Malang: Penerbit Gandum Mas, 1972), p. 65.

${ }^{15}$ Wartel A. Elwell, Robert W. Yarbrough, Encountering The New Testament (Grand Rapids: Baker Book House Company, 1998), 339.

16 @1996 David Malick, http://www.bible.org. 
Tema utama surat Titus, yang juga menjadi tugas pokok Titus, tertulis dalam Titus 2:1: "Tetapi engkau, beritakanlah apa yang sesuai dengan ajaran yang sehat." Paulus menegaskan Titus akan tugas utamanya yaitu memberitakan apa yang sesuai dengan ajaran yang sehat. Apa yang sesuai dengan ajaran yang sehat, itu menjadi isi pemberitaan Titus. Dan segala pemberitaan atau pengajaran Titus harus sesuai dengan ajaran yang sehat itu.

Apakah yang dimaksudkan Paulus dengan "ajaran yang sehat" di sini? Istilah "ajaran sehat" dalam Titus 2:1 diterjemahkan dari frasa Yunani $\tau \hat{n}$

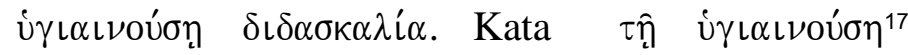
adalah partisip dari kata kerja i $\gamma\llcorner\alpha \iota \nu \omega$ yang memiliki pengertian "terdengar, menjadi baik, menjadi berada dalam kesehatan yang baik: doktrin yang benar dan tidak dikorup. ${ }^{18}$ Dalam konteks ini berarti pengajaran yang benar, doktrin yang benar dan tidak dikurangi atau dikorupsi. Dan kata $\delta\llcorner\delta \alpha \sigma \kappa \alpha \lambda i \alpha$ yang adalah kata benda yang berarti "pengajaran, apa yang diajarkan, doktrin. ${ }^{19}$ Kontek menunjukkan bahwa "ajaran sehat" adalah perkataan yang benar tepatnya adalah firman atau kata-kata atau perkataan atau berita yang setia, ${ }^{20}$ terjemahan

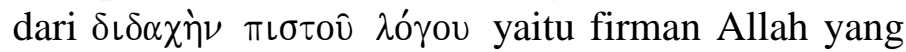
dapat dipercaya. ${ }^{21}$

Dengan demikian "ajaran sehat" adalah doktrin yang murni, yang diakui sebagai standard doktrin yang menunjukkan kehidupan yang benar dan yang harus diajarkan, ${ }^{22}$ yang berasal dari firman Allah yang dapat dipercaya. Dalam Titus 2:15, Paulus sekali lagi mengingatkan tugas Titus supaya ia "Beritakanlah semuanya itu, nasihatilah dan yakinkanlah orang dengan segala kewibawaanmu. Janganlah ada orang yang menganggap engkau rendah." Kemudian Paulus melanjutkan hal-hal yang perlu diingatkan kepada sidang jemaat, yaitu tentang perilaku Kristiani yang benar yang seharusnya nampak dalam kehidupan orang percaya.

\footnotetext{
${ }^{17}$ ư

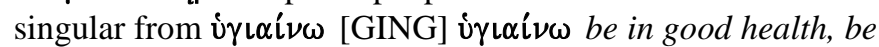
healthy or sound -1. lit. Mt 8:13 v.1.; Lk 5:31; 7:10; 15:27; $3 \mathrm{~J}$ 2.-2. fig. be sound or correct $\underline{1 \mathrm{Ti} 1: 10} ; \underline{6: 3} ; \underline{2 \mathrm{Ti} 1: 13} ; \underline{4: 3}$; Tit $\underline{1: 9}, \underline{13} ; 2: 1 \mathrm{f}, *$ [hygiene] [pg 204]

${ }_{18}$ Thayer, "Greek Lexicon"(C) 1992-2005 BibleWorks, LLC. ${ }^{19}$ Ibid.

${ }^{20}$ Titus 2:1 dalam berbagai terjemahan: ${ }^{\mathrm{KJV}}$ But speak thou the things which become sound doctrine: ${ }^{\mathrm{RSV}}$ But as for you, teach what befits sound doctrine. ITB Tetapi engkau, beritakanlah apa yang sesuai dengan ajaran yang sehat:

${ }^{21}$ Merryl C. Tenney, New Testament Survey ( Grand Rapids:

Wm.B. Publishing Co., 1985), 339.

${ }^{22}$ Ibid.338
}

\section{Isi Ajaran yang Sehat dalam Kitab Titus}

Di atas dijelaskan bahwa ajaran sehat berasal dari firman Allah yang dipercaya. Ajaran- ajaran tersebuat adalah sebagai berikut.

\section{Ajaran Mengenai Allah}

Allah dijelaskan sebagai Allah yang Pribadi; terbukti Dia melakukan tindakan sebagai Pribadi. Ia menyelamatkan semua mansuia $(2: 11)$, mengasihi manusia (3:6), memerintah (1:2). Selain itu Ia menunjukkan kualitas kasih $(2: 11)$ dan kemurahanNya (3:4). Ia tak bersdusta dalam menepati janji (1:3). Ia bergelar juruselamat (2:10); Bapa (1:4). Allah memiliki hamba (1:1) dan umat pilihan (1:1). Ia berdaulat adalam menyatakan firmanNya (1:3).

\section{Ajaran Mengenai Kristus}

Di dalam surat Titus terlihat bahwa semua pekerjan baik dan kelakuan orang percaya berhubungan dengan pribadi dan karya Kristus. ${ }^{23}$ KeilahianNya terlihat dalam frasa "Allah yang Mahabesar dan Juruselamat kita Yesus Kristus," (2:13) serta karya keselamatanNya terlihat dalam 2:11 yaitu "Karena kasih karunia Allah yang menyelamatkan semua manusia sudah nyata". Frasa "Allah yang Mahabesar dan Juruselamat kita Yesus

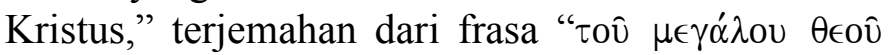

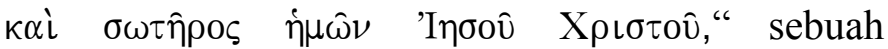
kontruksi tata bahasa Yunani yang disebut "kaidah Granville Sharp". Menurut kaidah ini jika ada dua kata benda tunggal yang bukan nama diri

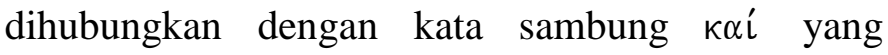
didahului dengan sebuah artikel berarti menunjuk pada satu pribadi ${ }^{24}$, artinya Allah yang Mahabesar dan Juruselamat itu satu pribadi yaitu Yesus Kristus.

\section{Ajaran Mengenai Roh Kudus}

Titus 3:5 menjelaskan bahwa keselamatan bukanlah hasil karya orang percaya , tetapi karena rahmat-Nya oleh permandian kelahiran kembali dan oleh pembaharuan yang dikerjakan oleh Roh Kudus. Kata pembaharuan di sini menggunakan istilah $\dot{\alpha} \nu \alpha \kappa \alpha \iota \nu \omega \dot{\sigma} \sigma \epsilon \omega \varsigma$ yang berasal dari kata $\dot{\alpha} \nu \alpha \kappa \alpha \iota \dot{\iota} \nu \omega \sigma \iota \varsigma$ yang berarti: sebuah pembaharuan, renovasi, suatu

\footnotetext{
23 (C)1997, 1998, 1999 Biblical Studies Press cd

${ }^{24}$ Ray Summer, Diktat Yang Pokok dalam Bahasa Yunani Perjanjian Baru terjemahan Petrus Maryono (Yogyakarta: STII nd), 154-155
} 
perubahan yang utuh untuk menjadi lebih baik. ${ }^{25}$ Roh Kudus mengerjakan suatu pembaharuan, renovasi, suatu perubahan yang utuh (komplit atau menyeluruh) untuk menjadikan orang-orang percaya pribadi yang lebih baik.

\section{Ajaran Mengenai Keselamatan}

Pertama-tama keselamatan adalah karya Allah Tritunggal (Tit. 2: 4-6). Keselamatan adalah kemurahan Allah (ayat 4). Yesus yang melaksanakan karya penyelamatan dengan menyelamatkan orang-orang percaya (ayat 5), dan Roh Kudus mengerjakan pembaharuan dalam diri orang-orang percaya (ayat 5).

Kedua, keselamatan adalah kemurahan Allah (ayat 4). Kemurahan yang dimaksud adalah '́ $\lambda \in 0 \varsigma$ suatu manifestasi yang terlihat dari belas kasihan yang memenuhi keperluan yang mendapatkannya ${ }^{26}$ Yesus Kristus menyatakan belas kasihan Allah melalui penyelamatan $(2: 11)$ dengan menyerahkan DiriNya (2:14) yang dalam ayat ini disebut sebagai Juruselamat. Menyerahkan diriNya bagi kita (orang

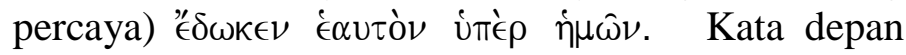
u̇т̇́ $\rho$ mengandung makna "sebagai ganti" (in the place of, instead of ${ }^{27}$ ). Dalam keselamatan Yesus berfungsi sebagai substitusi $\dot{\eta} \mu \omega \hat{\nu}$. Tujuan ( $\check{\iota} \nu \alpha-$ supaya) substisusi adalah supaya : Pertama-tama

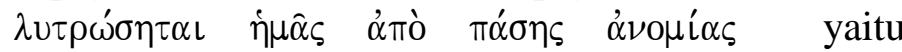
pembebasan dengan membayar harga ${ }^{28}$ orang percaya dari segalakejahatan. Pembebasan ini sekali untuk seterusnya (aorist). Dan tujuan substistusi

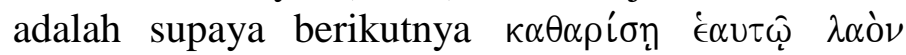
$\pi \epsilon \rho \iota$ $\sigma \iota \nu$, menyucikan (aorist) bagi DiriNya sendiri umat pilihan. Ini berarti orang percaya karena pengorbanan Yesus sebagai substitusi telah bebas dari segala kejahatan dan disucikan menjadi umat kepunyaan Allah sendiri pembebasan itu sekali untuk seterusnya. Lebih dari pada itu orang yang sudah dibebaskan dan dikuduskan adalah $\zeta \eta \lambda \omega \tau \eta े \nu$ $\kappa \alpha \lambda \omega \nu$ " $\rho \gamma \omega \nu$ yang artinya antusias berbuat baik (NET).

Paulus menuliskan bahwa keselamatan adalah bukan karena perbuatan baik yang telah jemaat lakukan (ayat 5) tetapi karena rahmat-Nya (kata Yunani $\in \lambda \in O \varsigma$ ) oleh permandian kelahiran

\footnotetext{
25 341; TDNT - 3:453,388; $\mathrm{n}$ f. Usage: AV - renewing 2; 2

${ }^{26}$ Vine's Expository Dictionary of Biblical Words, PC Study Bible V5. OC for Windows 1988-2006 Jim Gibertson

${ }^{27}$ Thayer "Greek Lexicon"(C) 1992-2005 BibleWorks, LLC.

${ }^{28}$ Ibid
}

kembali dan oleh pembaharuan yang dikerjakan oleh Roh Kudus. yang sudah dilimpahkan-Nya kepada kita oleh Yesus Kristus, Juruselamat kita (ayat6). Di sini jelas sekali bahwa Allah menyatakan kemurahan, kasih dan rahmat, Roh Kudus melahirkan kembali, dan pemandian Roh Kudus itu terjadi karena AnakNya Yesus Kristus yang melimpahkan Roh itu. Kemudian, orang percaya yang telah dibenarkan dan serta dikuduskan bagi diri-Nya menjadi umat kepunyaan-Nya sendiri, yang rajin (antusias) berbuat baik (2:14) berhak memperoleh hidup yang kekal (3:7).

\section{Ajaran Mengenai Perbuatan Baik}

Walaupun penebusan dan pengudusan dilakukan oleh pengorbanan Yesus itu sekali untuk selamanya, namun orang percaya perlu menghasilkan perbuatan baik. Dalam surat yang pendek ini kata "perbuatan baik" muncul enam kali $(1: 16 ; 2: 7,14 ; 3: 5,8,14)$. Perbuatan baik dalam 1:16 dihubungkan dengan pengenalan dengan Allah. Dalam 2:7 dihubungkan dengan menjaga firman (2:5) Allah dan kemuliaan Allah (2:9). Dalam 2:14 dihubungkan dengan keselamatan. Dalam 3:5 dinyatakan bahwa perbatan baik bukan syarat keselamatan. Dalam 3:8 berhubungkan dengan iman. Dan dalam 3:14 perbuatan baik disarankan dilakukan oleh orang beriman.

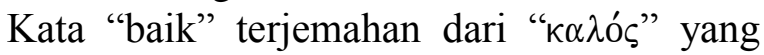
artinya indah dalam penampilan luar, namun menunjukkan kualitas yang dimaksud, dalam Titus 2:7 menunjuk kepada moral yang baik, mulia, patut dipuji, yang merupakan kontribusi keselamatan ${ }^{29}$ Dari ayat-ayat tersebut dapat disimpulkan bahwa keselamatan bukan karena perbuatan baik, tetapi sebaliknya perbuatan baik merupakan produk orang beriman melalui kasih karunia Allah $^{30}$

\section{Ajaran Sehat Dasar Pelayanan Paulus dan Titus}

Dalam pendahuluannya Paulus menyatakan

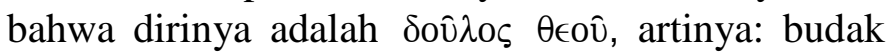

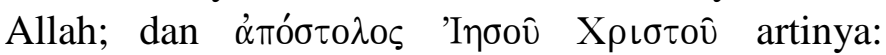

\footnotetext{
${ }^{29}$ William F.Arndt dan F. Wilbur Gingrich, “ A Greek-English Lexicon of the New Testament and Other Early Christian Literatus", terjemahan dariWalter"s Bauer (The University of Chicago Press, 1987), 400

${ }^{30}$ Biblical Studies Press Titus cd
} 
orang yang diutus Yesus Kristus. Dia menjadi budak dan utusan Allah adalah menurut

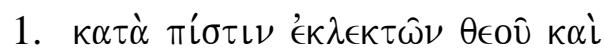

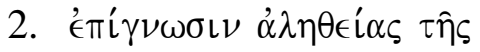

3. $\kappa \alpha \tau^{\prime} \in \dot{v} \sigma \epsilon \in \beta \in L \alpha \nu \ldots .$.

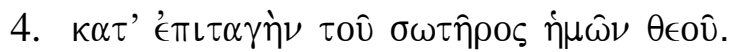

Ada empat hal yang mengikuti preposisi $\kappa \alpha \tau \dot{\alpha}$ yang menjelaskan dasar Paulus menjadi budak Allah dan utusan Yesus Kristus. Empat hal itu adalah:

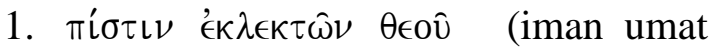

$$
\begin{aligned}
& \text { pilihan Allah); } \\
& \text { 2. } \dot{\epsilon} \pi i \gamma \nu \omega \sigma\left\llcorner\nu \quad \dot{\alpha} \lambda \eta \theta \in \epsilon^{\prime} \alpha \varsigma\right. \text { (pengetahuan } \\
& \text { kebenaran) } \\
& \text { 3. } \epsilon \cup ̉ \sigma \epsilon ́ \beta \in\llcorner\alpha \nu \text { (ibadah); }
\end{aligned}
$$

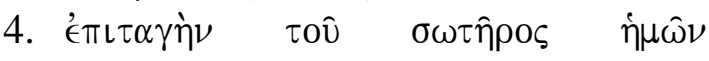

Dengan demikian empat hal ini adalah dasar dari pelayanan Paulus, yaitu: iman umat pilihan Allah, pengetahuan kebenaran, ibadah dan perintah Allah Juruselamat kita.

Paulus mengingatkan bahwa Titus adalah "anaknya yang sah dalam iman (1:4). Selain itu ia menasihati Titus bagaimana caranya menghadapi guru-guru palsu ${ }^{31}$. Ia minta supaya Titus menegor dengan tegas (1:13b) mereka yang tidak tertb. Ia menasihati supaya Titus memberitakan apa yang sesuai dengan ajaran yang sehat $(2: 1)$; Ia menasihati supaya Titus menjadi teladan dalam berbuat baik (2:7a); jujur dan sungguh-sungguh dalam pengajaran (2:7b).

Ia juga memberi nasihat supaya Titus memberitakan semua hal cocok dengan doktrin keselamatan (2:15a) serta diminta meyakinkan dengan kewibawaan (2:15b) dan secara negative diminta supaya jangan ada orang yang menganggap dia muda $(2: 15 \mathrm{c})$.

\section{Ajaran tentang Penatua Gereja (Titus 1:5-9)}

Titus ditinggalkan Paulus di Kreta adalah dengan tujuan untuk mengangkat penatua-penatua dan mengatur apa yang masih perlu untuk dilakukan. Karena itu Paulus mendaftarkan syarat yang dituntut bagi pemegang jabatan ini. Mereka harus

benar secara moral sesuai dengan ajaran yang sehat.

$$
\text { Istilah "penatua-penatua" dipakai }
$$

$\pi \rho \in \sigma \beta u \tau \epsilon ́$ pous. Ini adalah bentuk kata ganti ajektif

\footnotetext{
${ }^{31}$ Ibid
}

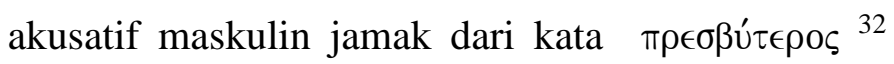
yang artinya tua-tua, penatua, biasanya orang yang tua secara umur juga, seorang yang ditetapkan secara resmi menjadi seorang penatua atau tua-tua sidang. Dipakai di antara orang-orang Yahudi dan di antara orang-orang Kristen. ${ }^{33}$

Di dalam Perjanjian Baru, terdapat dua kata khusus yang perlu diperhatikan, di saat kata ini masuk dalam definisi kata "penatua" dalam Perjanjian Baru. Yang harus diingat adalah konsep kepenatuaan Perjanjian baru pada dasarnya adalah kelanjutan dari jabatan Perjanjian Lama, yang disesuaikan dengan keadaan Jemaat lokal. ${ }^{34}$ Kedua kata ini adalah "penatua" 35 dan "penilik jemaat."36

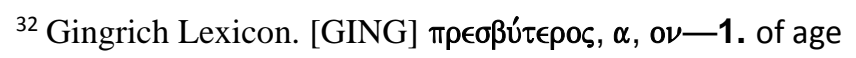
older, often subst. old(er) person Lk 15:25; J 8:9; Ac 2:17; 1 Ti 5:1f. Of a period of time oi $\mathrm{p}$ ) the men of old, our ancestors $\underline{\text { Mt 15:2 }}$, Mk 7:3, $\underline{5} ; \underline{\text { Hb 11:2. }}$ - - 2. as a designation of an official elder, presbyter - a. among the Jews Mt 16:21; 27:41; $\underline{\text { Mk 14:43 }}, \underline{53} ; \underline{\text { Lk 7:3}} ; \underline{9: 22} ; \underline{\text { Ac } 4: 23} ; \underline{6: 12}$. - b. among the Christians Ac 11:30; $14: 23 ; 1$ Ti 5:17, 19; Tit 1:5; Js 5:14; $1 \mathrm{Pt}$ $\underline{5: 1} ; \underline{5: 5} ; \underline{2 \mathrm{~J} 1} ; \underline{3 \mathrm{~J} 1} ; \underline{\mathrm{Rv} 4: 4} ;$ 7:11. [Cf. priest, Old English preost via Latin presbyter.] [pg 167]

${ }^{33}$ Di dalam Perjanjian lama, bahasa Ibrani yang dipakai adalah "zagen" (SC2205) yang artinya "tua" diterjemahkan

"berumur, manusia purba, tua-tua, tertua, orang tua, pria dan wanita, senator" (Kej. 10:21; 25:23; U1. 5:23' I Sam. 4:3; I Taw. 11:3). Bahasa Kaldea "Siyb" (SC7868) yang artinya "menjadi tua, usia senja" juga dipakai untuk "penatua" (Ez. 5:5, 9; 6:7, 8, 14). Arti dasar dari kata "penatua" seperti yang dipakai dalam Perjanjian Lama, merujuk pada orang yang lebih tua atau sudah tua, baik pria maupun wanita. Oleh karena itu, kata ini tidak berbicara tentang orang muda, orang baru dalam hal kebijaksanaan pengalaman yang pada umumnya datang seiring dengan waktu. Bagaimanapun juga, sebagaimana akan dibahas terdapat sebuah perkembangan menarik dari peran para penatua, bahkan dalam pemakaian dari kata ini di dalam Perjanjian Lama.

${ }^{34}$ Kevin J. Conner, Jemaat dalam Perjanjian Baru (Malang: Penerbit Gandum Mas, 2004), p. 237.

${ }^{35}$ Perhatikan beberapa kata Yunani, dan menghubungkan katakata yang relative dekat dengan istilah kepenatuaan. 1) Presbuteros $(\mathrm{SC} 4245)=$ "penatua, orang yang lebih tua atau senior." Diterjemahkan "penatua." Kata ini diterapkan dalam beberapa cara: a. bagi orang yang lebih tua yang meningkat dari tahun ke tahun ke tahun, baik pria yang lebih tua atau wanita lebih tua, sebagai senior (Yoh. 8:9; Luk. 15:25; Kisah 2:17; I Tim. 5:2; Filmn. 9; Luk. 1:18; Tit. 2:2,3); b. Bagi orang-orang kudus dan kepala keluarga Perjanjian lama (Ibr. 11:2), dan orang-orang Perjanjian Lama yang membentuk tradisi-tradisi yang meniadakan Firman Allah (Mat. 15:2; Mark. 7:3-5); c. Bagi perwira-perwira bangsa Yahudi (Luk. 7:3), baik Rumah-rumah ibadat lokal maupun Mahkamah Agama bangsa Yahudi yang disebut sanhedrin (Mat. 5:22; 10:17; 16:21; 21:23; 26:3, 47, 57, 59; 27:1 3, 12 20, 41; Luk. 22:66; Kisah 4:5-8; 6:12; 23:14; 24:1; 25:15; Mark. 13:9; $14: 55)$ ' d. Bagi pemimpin-pemimpin yang jabatannya ditahbiskan dalam Jemaat Perjanjian Baru atau Jemaat-jemaat lokal (Kisah 14:23; 20:17, 18; I Tim. 5:1, 2, 17-19; Tit. 1:5; 
Sebuah studi yang sangat teliti dari kata-kata ini dalam Kitab Suci, menunjukkan bahwa ada hubungan yang dekat antara kata-kata itu, dan mereka berbicara tentang satu jabatan yang sama. Beberapa orang telah mencoba membuat perbedaan di antara kata-kata itu meninggikan satu dari yang lain, dan dengan demikian menciptakan aturanaturan yang tidak alkitabiah bagi para penilik jemaat dan para penatua. Beberapa sumber Yunani

Yak. 5:14; I Pet. 5:1). Kata ini muncul 66 kali dalam Perjanjian Baru 12 di antaranya di dalam Kitab Wahyu. 2) Presbuterion $(\mathrm{SC} 4244)=$ "Majelis yang beranggotakan orang-orang berumur lanjut, atau Urutan Para Penatua." a. Ini dibandingkan dengan Mazmur 107:32 yaitu "majelis para penatua"; b. Ini diterapkan pada Dewan atau Senat atau Sanhedrin Bangsa Yahudi yang terdiri daru 70 Penatua (Lukas 22:66; Kisah 22:5); c. Ini diterapkan pada kelompok penatua dalam Jemaat Lokal dan diterjemahkan menjadi "presbiter" (I Tim. 4:14). Ini sematamata merujuk pada kelompok penatua manapun, yang bersekutu bersama dalam sidang. Gereja Presbiterian memperoleh namanya dari bentuk Pemerintahan Gereja ini. Kata ini muncul tiga kali dalam Perjanjian Baru. 3) Sumpresbuteros (SC4850) = "penatua sekerja." Hanya dipakai sekali dlam I Petrus 5:1. harfiahnya berarti penatua bersama. Petrus adalah seorang penatua, penatua bersama dengan penatua-penatua dalam jemaat.

${ }^{36}$ Kata Yunani yang diterjemahkan dengan kata "penilik jemaat" dalam Alkitab bahasa Indonesia, adalah episkopos. Bentuk-bentuk kata ini yang berhubungan dengan penilik jemaat adalah: 1) Episkopos (SC1985) = "seorang pengawas, pimpinan, pelindung." Dalam bahasa Yunani, kata ini adalah hasil gabungan dari dua kata. Yaitu, preposisi "epi" yang berarti "melebihi:, dan kata "skopos" yang berarti "melihat atau mengamati, memandang dengan tajam, mengawasi" (EC1909 dan 4649). Kata ini dipakai lima kali dalam Perjanjian Baru dan diterjemahkan: penilik (Kisah 20:28) dan para penilik jemaat (Fil. 1:1; 1 Tim. 3:2; Titus 1:7; I Pet. 2:25). Kata ini berbicara tentang pegawai Kristen dalam tugas umum di gereja. Thayers menyebutnya "seorang pengawas, seseorang yang berurusan dengan tugas mengawasi segala sesuatu yang harus dilaksanakan oelh orang lain dengan benar, pengawas,

pelindung atau pimpinan manapun." Vine menyatakan "dalam Gereja-gereja Kristen, mereka yang diangkat dan dimampukan oleh pekerjaan Roh Kudus, ditunjuk untuk memiliki kepedulian rohani, dan untuk menjalankan pengawasan terhadap Gerejagereja." Wuest berkomentar "kata yang asli datang dari kehidupan sekular, merujuk pada mandor dari kelompok kontruksi atau pengawas dari pembangunan gedung, misalnya." Gereja Keuskupan menekankan bentuk Pemerintahan ini sesuai dengan sebutannya. 2) Episkope (SC1984) = bentuk kata benda dari "episkopos", yang berarti "pemeriksaan (untuk pembebasan), dalam pengertian sebagai pengawas, khususnya melalui istilah "episkopat" Kristen, yaitu jabatan penilik jemaat. Kata ini diterjemahkan: Keuskupan (Kisah 1:20), Penilik jemaat (I Tim. 3:1), Lawatan (Luk. 19:44; I Pet. 2:12). Ini berkaitan dengan pemeriksaan, lawatan, pengusutan, jabatan kepengawasan. 3) Episkopeo (SC 1093) = bentuk kata kerja dari "episkopos", yang berarti "mengawasi, dengan pengertian, berhati-hati." Diterjemahkan "jagalah" (Ibr. 12:15), dan "gembalakanlah" (I Pet. 5:2). menunjukkan bahwa "penatua" merujuk pada manusia, dan "penilik jemaat" merujuk pada jabatan. Dikatakan juga bahwa kata "penatua" memiliki latar belakang bahasa Ibrani sebagaimana kata "penilik jemaat" memiliki latar belakang bahasa Yunani, akan tetapi keduanya adalah penjelasan dari irang yang sama dengan jabatan yang sama. Tidak ada pemikiran mengenai peninggian satu di atas yang lain dari pemakaian kata-kata ini. ${ }^{37}$

Perhatikanlah ayat-ayat berikut ini. Petrus mengangkat "penatua-penatua" (Yunani

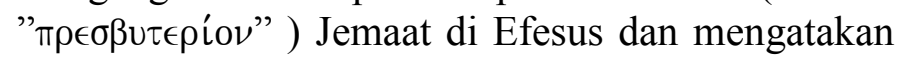
bahwa mereka adalah "para pengawas" (Yunani "єাıбкотоৎ"), Kisah Para Rasul 20:17, 28, dan menyuruh mereka supaya "memberi makan"

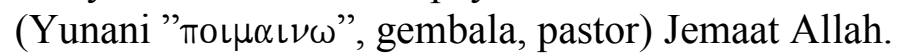
Paulus memerintahkan Titus untuk menahbiskan

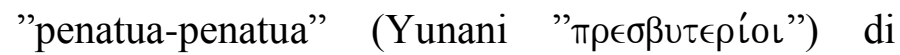
setiap kota, dan menetapkan suatu aturan bagi "para

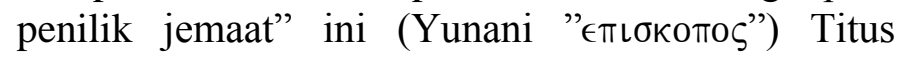
1:5,7. Petrus yang adalah seorang "penatua" (Yunani " $\pi \rho \in \sigma \beta u \tau \epsilon \rho i ́ o \varsigma ")$ berbicara kepada "penatua-penatua" (Yunani " $\pi \rho \in \sigma \beta u \tau \epsilon \rho$ íol"), dan memerintahkan supaya mereak "memberi makan"

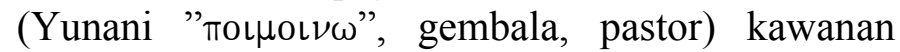
domba Allah, "gembalakanlah" (Yunani

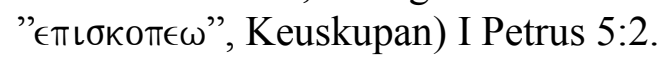

Dengan demikian, seorang penatua adalah seorang penilik jemaat, dan seorang penilik jemaat adalah seroang penatua. Penatua adalah manusia, yang memiliki kedewasaan dalam pengalaman bukan sebagai orang baru. Penilik jemaat adalah jabatan atau posisi yang dia pegang. Menggembalakan adalah pekerjaan yang dilakukannya. Jadi dapat disimpulkan bahwa statusnya adalah penatua atau presbiter, tugasnya adalah penilik jemaat atau pengawas, fungsi dan pekerjaannya adalah pastor, gembala. Vine menyatakan bahwa istilah "penatua" menunjukkan kedewasaan pengalaman rohani dari mereka yang ditunjuk; sedangkan istilah "penilik jemaat" atau "pengawas" menunjukkan karakter dari pekerjaan yang mereka jalankan. ${ }^{38}$

Jadi kesimpulannya adalah bahwa: penatua, penilik jemaat dan gembala berbicara tentang satu orang yang sama. Ini merujuk pada pelayanan dalam bentuk menjaga, menuntun memberi makan,

\footnotetext{
${ }^{37}$ Kevin J. Corner p. 240.

${ }^{38}$ W.E. Vine, The Expanded Vine's Expository Dictionary of New Testament Words (Minneapolis: Bethany House

Publishers, 1984), p. 350-351.
} 
memerintah, mengajar dan melindungi dengan sungguh-sungguh para kawanan domba Allah yang dilakukan oleh para pemimpin yang Allah tunjuk. Sebagai seorang penilik jemaat, para penatua harus bisa menjaga dan sebagai seorang gembala, para penatua harus bisa merawat serta memberi makan setiap kawanan domba Allah.

Kepenatuaan merupakan bentuk pemerintahan jemaat Perjanjian Baru. Para penatua ditetapkan di setiap jemaat (Kisah 14:23; 20:17). Kisah 14:23 adalah yang pertama kali menyebutkan penatua-penatua dalam jemaat Perjanjian Baru. Titus 1:5 Paulus memerintahkan Titus untuk menetapkan para penatua di setiap kota. Jemaat Perjanjian baru adalah universal dalam jangkauannya, tetapi bersifat lokal dalam ekpresi geografisnya. Dengan demikian penatua-penatua pada masa Perjanjian Baru adalah penatua-penatua jemaat yang ada dalam satu kota manapun, tempat jemaat dibangun. Mereka adalah penatua gereja kota. Ini terdiri dari dewan penatua, majelis atau tingkatan penatua (I Tim. 4:14).

Kwalifikasi yang disebutkan Paulus kepada Titus berkenaan dengan persyaratan seorang penatua adalah orang-orang yang tak bercacat, yang mempunyai hanya satu isteri, dan yang anakanaknya hidup beriman dan tidak dapat dituduh karena hidup tidak senonoh atau hidup tidak tertib. Sebab sebagai seorang pengatur rumah Allah, seorang penilik jemaat harus tidak bercacat, tidak angkuh, bukan pemberang, bukan peminum bukan pemarah, dan tidak serakah, melainkan sebaliknya, seorang penilik jemaat haruslah seorang yang suka memberi tumpangan, suka akan yang baik, bijaksana, adil, saleh, dapat menguasai diri dan berpegang kepada perkataan yang benar, yang sesuai dengan ajaran yang sehat. Tujuannya adalah supaya para penilik jemaat sanggup menasehati orang berdasarkan ajaran itu dan sanggup meyakinkan penentang-penentangnya.

\section{Kualifikasi Karakter}

Seorang penatua haruslah seorang yang cakap sebelum diterima dalam jabatan umum. Tidak seorangpun mengharapkan jemaat untuk memiliki kepercayaan dan hormat pada jabatan kepenatuaan, kecuali jika orang-orang ini memenuhi syarat bagi jabatan kudus ini. Penekanannya lebih kepada karakter daripada kharisma, meskipun keduanya penting. Meskipun banyak kualifikasi yang dapat dan harus diterapkan kepada semua orang Kristen, seorang penatua harus memiliki kecakapankecakapan ini. Mereka tidak boleh memilih. Dalam Titus 1:7 (bandingkan 1 Tim. 3:2,7) kata "harus" dipakai untuk menekankan dalam kaitannya dengan kecakapan-kecakapan kepenatuaan. Kata tersebut berarti "ini adalah penting, atau ini adalah mengikat."

Frasa "yakni orang-orang yang..." dalam bahasa Yunani dimulai dengan kata $\epsilon "$ yang tidak diterjemahkan dalam bahasa Indonesia. ${ }^{39}$ Istilah $\epsilon$ "l memiliki pengertian "if; wether; that; if only, surely; since." Tetapi penggunaan dalam rangkain $\epsilon "$ bersama kata ganti $\tau \iota \varsigma$ atau $\tau \iota$ menjadikan $\epsilon "$ $\tau \iota \varsigma$ dan $\epsilon " l$ $\tau \iota$ memiliki arti what (ever). ${ }^{40}$ Istilah $\epsilon "$ menunjuk kepada suatu kondisi atau keadaan, baik itu nyata ataupun hipotetis, aktual atau bertentangan dengan kenyataan. ${ }^{41}$ Seorang penilik jemaat haruslah seorang yang sedang dalam kondisi yang seharusnya dalam suatu kepastian yang tidak dapat digoyahkan, siapapun dia, seorang penilik jemaat adalah seorang yang: "tidak bercacat, yang mempunyai hanya satu isteri, dan sebagainya". $\epsilon$ " sendiri adalah suatu partikel kondisional yang dikaitkan dalam suatu kondisi yang bersifat umum, baik itu sesuai dengan kondisi nyata ataupun kontras. ${ }^{42}$

Istilah " $\epsilon \sigma \tau \iota \nu$ menunjuk kepada suatu keberadaan yang sedang berjalan, yaitu "sedang adalah" seseorang yang dalam keadaan saat itu $\dot{\alpha} \nu \epsilon^{\prime} \gamma \kappa \lambda \eta \tau \mathrm{c}, \quad$ Istilah ini berarti: blameless,

\footnotetext{
${ }^{39}$ Dalam Alkitab terjemahan bahasa Inggris pada umumnya diterjemahkan dengan istilah "if" (ASV, KJV, NAS, RSV) sementara dalam versi NAB diterjemahkan "on condition" ${ }^{40}$ UBS lexicon, 1796.

${ }^{41}$ Louw Nida Lexicon, 89.65.

${ }^{42}$ Lihat catatan no. $1886 \mathrm{\epsilon} \mathbf{l}$-1. conditional particle if: with indicative in general conditions Mt 4:3; 26:33, 42; Lk 16:11f; Ro 2:17 or in contrary-to-fact conditions (see a;n) Mt 11:21; Lk 7:39; J 9:33. With subjunctive Rv 11:5. With optative in a future less vivid (should-would) condition Ac 24:19; $1 \mathrm{Pt}$ 3:14, 17; eiv tu,coi it may be, for example, perhaps 1 Cor 14:10; 15:37. If = since Mt 6:30; J 7:23; Ro 6:8. After verbs of emotion that Mk 15:44a; Ac 26:23; $1 \mathrm{~J} 3: 13$. In strong assertions, with the apodosis omitted eiv has a negative effect

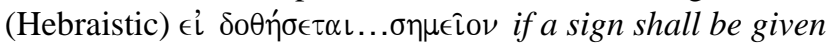
(something fearful will result), hence $a$ sign will certainly not be given $\mathrm{Mk} 8: 12$; cf. $\mathrm{Hb} 4: 3,5$. -2. interrogative particle: with direct questions, eiv is left untranslated Mt 12:10; Lk 13:23; Ac 1:6. With indirect questions whether, if Mt 26:63; Mk 3:2; Ac 17:11.-3. with other particles $\epsilon \dot{\imath} \delta \dot{\epsilon} \mu$ í if not,

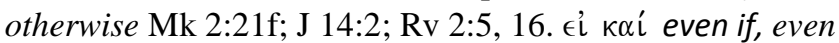
though Lk 11:8; 1 Cor 7:21. eiv mh, except, if not Mt 5:13; 11:27; Ro 7:7; Gal 1:19 or but Mt 12:4; Gal 1:7. $\epsilon$ " $\pi \omega \varsigma$ if perhaps, if somehow Ac 27:12; Ro 1:10. Gingrich Lexicon [pg $55]$
} 
irreproachable yaitu "tidak bercacat, tidak dapat tersentuh."43 Kata ini dipakai hanya empat kali dalam Alkitab yaitu: 1 Korintus 1:8, Kolose 1:22; I Timotius 3:10 dan Titus 1:6. Hal yang menarik adalah bahwa di dalam I Korintus 1:8, kata ini dipakai dengan pengertian menunjukkan kepada keadaan jemaat Tuhan atau gereja Tuhan pada waktu Kedatangan Kristus kedua kali, dimana jemaat dalam keadaan tidak bercacat. Sementara dalam Kolose 1:22 dituliskan bahwa jemaat telah diperdamaikan dengan Allah oleh kematian Kristus untuk menempatkan jemaat kudus dan tak bercela dan tak bercacat di hadapanNya. Dan dalam kedua ayat yang terakhir, yaitu I Timotius 3:10 dan Titus 1:6, keadaan "tidak bercacat" adalah persyaratan yang dituntut dari seorang diaken dan seorang penilik jemaat.

Dari sini dapat disimpulkan bahwa seorang penilik jemaat dituntut untuk memberikan kualitas kerohanian yang tertinggi dan terbaik, dimana untuk itulah Kristus menyerahkan diriNya, dan demikianlah keadaan gereja pada Kedatangan Kristus kedua kali, yaitu tidak bercacat. Seorang penilik jemaat seharusnya terlebih dahulu memberikan teladan dan contoh hidup bagaimanakah kehidupan yang tidak bercacat tersebut.

Seorang penatua seharusnya memiliki integritas yang tidak diragukan lagi, tidak bercela. Tidak dapat ditemukan kesalahan ataupun layak untuk dikecam. Tingkah laku seorang penatua harus menjadi teladan bagi kawanan domba Allah dan bebas dari noda skandal dan tuduhan. Dia harus berada di atas celaan, amarah atau cercaan (bandingkan Gal. 2:11; Fil. 2:15; 2 Pet. 3:14; 2 Kor. 6:3). Tidak ada tuntutan yang melawannya, tidak ada kesalahan yang diletakkan atasnya, oleh sebab kehidupan Kekristenannya. ${ }^{44}$

Seorang penatua tidak seharusnya mudah marah (Tit. 1:7). Seorang penatua tidak mudah marah atau cepat naik darah, lekas tersinggung, atau lekas marah. Tidak suka bertengar, menghasur unruk berselisih, berdebat secara picik, bercecok, gusar, geram, sembarangan, cepat naik darah. Seseorang bisa enjadi marah dan berdosa, ttapi tidak demikian apabila berasal dari Allah (Ef. 4:32). Ia pun adalah seorang yang dapat mengendalikan

\footnotetext{
${ }^{43}$ Gingrich Lexicon, p. 14.

${ }^{44}$ Versi Amplified Bible tidak memberi dasar tuduhan tetapi harus berada di atas celaan. Versi Phillips menjelaskan bahwa penilik jemaat harus memiliki reputasi yang tak bercacat. Versi Knox menjelaskan bahwa penilik jemaat haruslah seseorang yang di dalam dirinya tidak terdapat kesalahan.
}

rohnya sendiri, tidak suka bercekcok, tidak berargumentasi secara egois.

Seorang penatua seharusnya tidak menjadi pemberang (Tit. 1:7). Seorang penatua tidak bengis tidak suka melawan, atau tidak suka berkelahi. Tidak mencaci maki atau memukul membalas serangan atau memukul balik dengan tangan ataupun perkataan. Tidak menjadi seorang yang mudah putus asa (I Pet. 2:23; 1 Tim. 3:3). Ia adalah seorang yang tidak suka berkelahi, melainkan lemah lembut. Tidak menyerah pada kekerasan fisik, melainkan seseorang yang dibentuk oleh ketahanan dan kelembutan hati. Bukan seorang yang suka berkelahi atau meninju. Bukan seorang yang suka berperang.

Seorang penatua seharusnya bukan hamba uang (Tit. 1:7). Seorang penatua tidak mengejar uang seorang orang sewaan, pencuri atau perampok (1 Tim. 5:17, 18; 6:9-10; 1 Pet. 5:2; Kisah 20:1725). Tidak mengejar keuntungan. Tidak mendapatkan uang melalui cara yang tidak jujur, atau mendapatkan uang haram dengan cara apapun. Bebas dari cinta akan uang.

Seorang penatua seharusnya tidak mementingkan diri sendiri (Tit. 1:7). Seorang penatua tidak mementingkan diri sendiridalam arti memberikan diri kepada kehendak orang itu sendiri, dan tidak bersedia tunduk pada kehendak orang lain. Pementingan diri sendiri menyebabkan kejatuhan Lucifer (2 Pet. 2:4), demikian juga dengan kejatuhan Adam dan Hawa. Kehendak bebas manusia harus diserahkan kepada kehendak Allah yanng baik dan sempurna (Roma 12:1, 2; 2 Pet. 2:10; Dan. 11:36; Ef. 5:17).

Penatua pun harus orang yang tidak sombong, tidak keras kepala, tidak suka memaksa, tidak menyenangkan diri sendiri, tidak congkak, tidak egois, tetapi ia adalah seorang yang ada dalam kepatuhan pada kekuasaan Allah dan yang selalu mencari keharmonisan dengan kehendak penatuapenatua lainnya dengan didasarkan pada kehendak Allah. Ia juga bukan seornag yang keras kepala tegar tengkuk, tidak menghargai orang lain, keras hati, dan orang yang memaksakan. Termasuk juga bukan orang yang mencintai diri sendiri dan menempatkan diri sebagai pusat dari segala sesuatu. Di sisi lain ia juga bukan orang yang tidak sensitif dan selalu memaksakan kehendaknya kepada orang lain.

Seorang Penatua haruslah seorang yang dapat menguasai diri (Tit. 1:8). Ia harus dapat menunjukkan penguasaan diri, menahan diri, 
disiplin, mengendalikan diri, mampu memimpin diri sendiri dalam segala hal, dalam nafsu, dalam roh (Gal. 5:23). Pengendalian diri atas hasrat dan cinta. Kuat dalam suatu hal berkuasa penuh, bebas dari hal yang ekstim dan perbuatan berlebihan bersikap tidak berlebihan (Roma 12:14; 1 Kor. 9:25; 1 Tim. 3:2)

Seorang penatua haruslah seorang yang saleh (Tit. 1:8). Artinya ialah bahwa seorang penatua harus dapat berpikir saleh, bijaksana, berpikiran sehat, berhati-hati, menyuarakan gagasan. Tidak menyerah pada pemikiran khayalan atau emosi yang tidak logis. Menjalankan pertimbangan yang disuarakan. Sebuah pemikiran yang disiplin. Kecenderungan tanpa kesedihan (Tit. 2:2; 6:4, 12; 1 Pet. 1:13; Rm. 12:3; 1 Pet. 4:7; 5:2; 1 Tes. 5:6; Kisah 26;25). Sehat ingatan, lemah lembut, tenggang hati tidak irasional, waspada. Tertib, berhati-hati, bijaksana.

Seorang penatua haruslah seorang yang adil (Tit. 1:8). Seorang penatua harus budiman, patut, tulus, jujur, seksama bersungguh-sungguh, tidak memihak dalam semua campur tangannya, seperti seorang hakim di pengadilan. Tidak hanya berpendirian teguh di hadapan Allah dalam berurusan dengan orang lain tingkah laku yang benar. Adil dan tidak memihak. Mampu membuat keputusan obyektif berdasar atas prinsip.

Seorang penatua haruslah seorang yang kudus (Tit. 1:8). Ia haruslah seorang yang beriman, saleh, menyenangkan Allah dan menguduskan diri untuk melayani Tuhan. Ia tidak menyalahgunakan anugerah Allah, melainkan percaya, mengajar dan menjalankan kekudusan hidup, yang tanpanya tidak seorangpun dapat melihat Allah. Kudus dalam pikiran kata-kata, dan perbuatan, sama seperti Dia yang kudus (1 Pet. 1:15, 16; Ibr. 12:10, 14).

Seorang penatua haruslah seorang yang mengasihi Allah (Tit. 1:8). Maksudnya ialah mengasihi segala hal tentang Allah, orang-orang, kebenaran, kebajikan dan tindakanNya; bukan mencintai kejahatan atau dunia ini.

Seorang penatua haruslah seorang yang suka memberi tumpangan (Tit. 1:8). Ia adalah seseorang yang sayang kepada tamu-tamunya, dan baik kepada semua orang yang mereka terima di rumah. Memberi pertolongan kepada orang asing (Ibr. 13:2; 1 Tim. 5:10; Mat. 25:34-40).

\section{Kualifikasi Domestik}

Seorang penatua harus tidak bercacat dalam hal kehidupan rumah tangganya. Dalam Titus 1:7 dijelaskan sebagai berikut: "yang mempunyai hanya satu isteri, yang anak-anaknya hidup beriman dan tidak dapat dituduh karena hidup tidak senonoh atau hidup tidak tertib" (Tit. 1:6). Kualifikasinya adalah seorang penilik jemaat harus tidak bercacat dalam kehidupan rumah tangganya. Ia tidak boleh memberikan peluang atau kesempatan untuk diserang dari sisi kehidupan rumah tangganya. Ia seharusnya hanya mempunyai satu isteri dan kehidupan anak-anaknya beriman dan tidak dapat dituduh karena hidup yang tidak senonoh atau tidak tertib.

Ada banyak perdebatan tentang "yang mempunyai hanya satu isteri" di kalangan para penafsir Alkitab. Hal yang diperdebatkan adalah: apakah seorang penilik jemaat hanya boleh mempunyai satu isteri saja sepanjang umur hidupnya atau pada saat ia menjabat sebagai penilik jemaat saat itu ia hanya sedang memiliki satu isteri saja. Istilah Yunani yang dipakai untuk "yang

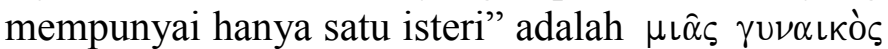

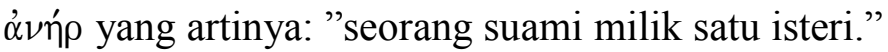
Tidak dijelaskan apakah saat itu ia hanya beristerikan satu orang saja, atau seumur hidupnya ia hanya boleh menjadi miliki satu perempuan. Jadi dia tidak boleh menikah kembali sekalipun ia telah menjadi duda karena ditinggal mati sang isteri terdahulu. Perdebatan cukup ramai membicarakan hal ini. Biasanya berkaitan dengan etika kehidupan Kristiani dan etika kehidupan dan pelayanan seorang pemimpin Kristen.

Seorang penatua tidak diharuskan menikah, tetapi apabila menikah ia harus menikahi satu isteri. Bukan beristri dua, atau poligami, melainkan suami dengan satu isteri. Hal ini mencakup di dalamnya moralitas Kristen; tidak berbuat zinah, atau bertingkah laku yang tidak bermoral. ${ }^{45}$ Rumah tangga penatua harus tertib.

Seorang penatua haruslah seorang pengatur rumah Allah (Tit. 1:7). Seorang pengatur adalah seorang pengelola rumah tangga (Yunani "оькороноs "). Seorang penatua adalah seorang pengelola rumah tangga Allah, seorang pelayan yang dipekerjakan untuk mengatur urusan-urusan Allah (1 Kor. 4:2; Luk. 12:42; 16:1,3,8; Rm. 16:23; Gal. 4:2; 1 Pet. 4:10). Hal ini harus tercipta dalam rumah tangganya sendiri terlebih dahulu, baru dilanjutkan di dalam rumah Allah.

Rumah tangga penatua harus menjadi teladan. Isteri seorang penatua haruslah terhormat (Tit. 2:2). Ia harus bijaksana (Tit. 1:8). Ini berarti

\footnotetext{
${ }^{45}$ Tidak ada catatan secara spesifik di sini tentang perceraian dan atau menikah kembali.
} 
ia berpikiran bijaksana dan berhati-hati, berpikiran sehat. Isteri yang bijaksana ini dapat mendukung suaminya dalam melaksanakan tugas penatua. Anak-anak seorang penatua harus beriman (Tit. 1:6) atau percaya kepada Yesus Kristus sebagai juruselamat pribadi mereka. Anak-anak penatua seharusnya tidak pernah dituduh karena hidup tidak senonoh (Tit. 1:6). Hidup tidak senonoh berarti bertingkah laku yang tidak terkendali, hingar bingar, mengganggu kedamaian, terlalu bergembira, suka ribut, berlaku liar, suka berpesta pora, bebas berbuat jahat, lawan dari kedamaian dan ketenangan. Anakanak penatua seharusnya tidak dapat dituduh karena bertingkah liar atau kehilangan moral atau pimpinan; melainkan harus menjadi teladan bagi anak-anak lainnya. Anak-anak penatua seharusnya bukan seorang yang hidup tidak tertib (Tit. 1:6). Hidup tidak tertib berarti tidak taat hukum, tidak teratur, suka melawan, suka memberontak, tidak dapat dikenadlikan, beringkah laku buruk, tidak tunduk, tidak memiliki peraturan. Anak-anak penatus tidak boleh tidak disiplin, tidak patuh, bebas, tidak dapat ditundukkan atau suka memberontak. Mereka harus patuh, dan penh hormat pada penguassa yang sebenarnya, baik penguasa Sipil maupun jemaat. Hal ini harus tampak dalam kehidupan rumah tangga mereka, di bawah wewenang orang tua.

\section{Kualifikasi Pelayanan}

Seorang penatua harus memegang erat Firman kesetiaam sebagaimana diajarkan padanya (Tit. 1:9). Dia harus memegang rahasia iman. Maksudnya ialah, tidak menjadi goyah dalam memegang diktrin, melainkan memegang teguh Firman Allah, iman yang pernah dikirimkan kepada orang-orang kudus, doktrin para rasul (Yud. 3; Kisah 2:42). Dia harus melekat, jarus bertekun pada Firman yang setia.

Seorang penatua harus mempu menasihati dan meyakinkan orang lain (Tit. 1:9). Ia harus mampu menasihati, yaitu: mengingatkan, membesarkan hati, memanggil, memohon, dengan doktrin yang diberitakan; dan juga meyakinkan, yaitu mnghukum, menegur, membetulkan dan meyakinkan mereka yang melawan, dan menentang pengajaran yang benar.

\section{Ajaran Mengenai Guru-guru Palsu dan Perlunya Membantah Mereka(Titus 1:10-16)}

Sejak abad pertama, gereja telah diganggu oleh orang-orang yang berusaha memutarbalikkan kebenaran sesuai dengan keinginan mereka atau 'memurnikannya" agar bisa lebih diterima atau lebih "masuk akal." yang sangat dikhawatirkan oleh jemaat mula-mula adalah tiga keompok bidat: kelompok orang yang me-yahudi-kan, penganut ajaran Gnostik, dan para pengikut Nikolaus.

Kelompok orang yang me-yahudi-kan menekankan pemeliharaan hukum Taurat secara sangat teliti. Pada mulanya gereja terdiri atas orangorang Yahudi yang bertobat, yang mengakui bahwa Yesus adalah Mesias, Yang Diurapi Allah. Tetapi ketika Paulus memulai pelayanannya di antara orang-orang bukan Yahudi, sebagian orang Yahudi yang sudah menjadi Kristen memperingatkan bahwa seorang bukan Yahudi tidak dapat menjadi Kristen kecuali kalau dia menjadi Yahudi terlebih dahulu. Mereka mengatakan bahwa orang-orang bukan Yahudi yang pindah agama menjadi Kristen harus melakukan upacara fisik seperti penyunatan dan taat pada hukum Taurat yang telah dilaksanakan orang Yahudi selama ratusan tahun (Kisah 15:1-31). Di Kreta sendiri dimana Titus melayani terdapat pula guru-guru palsu yang mengajarkan ajaran-ajaran ini.

Kelompok ajaran palsu yang kedua adalah penganut ajaran Gnostik, yang beranggapan bahwa Yesus bukan benar-benar Anak Allah. Mereka menganggap bahwa zat itu jahat dan roh itu baik. Karena Allah itu baik (dan Dia adalah roh), maka tidak mungkin Ia menciptakan dunia yang bersifat kebendaan ini (yang jahat). Lagi pula, mereka mengemukakan bahwa karena roh dan zat tidak dapat bercampur, Kristus dan Allah tidak mungkin bersatu di dalam diri Yesus. Mereka mengambil

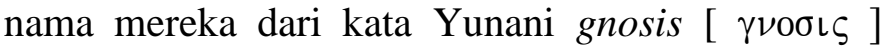
("pengetahuan"), serta mengakui bahwa mereka memiliki pengertian khusus mengenai kebenarankebenaran rahasia dalam hidup ini. ${ }^{46}$ Para ahli arkeologi telah menemukan beberapa naskah papirus orang Gnostik di Mesir. Beberapa di antaranya adalah tulisan-tulisan dengan nama pengarang palsu, seperti "Kebijaksanaan Yesus Kristus" dan "Perbuatan-perbuatan Petrus." mungkin buku Gnostik yang paling terkenal adalah

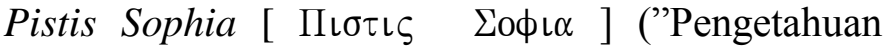
Iman"), yang telah diterjemahkan ke dalam bahasa Inggris dan Perancis. Banyak komunitas Gnostik yang tersebar di seluruh Timur Dekat. Setiap

\footnotetext{
${ }^{46}$ J.J. Packer, Merril C. Tenney, dan Willian White Jr. Ensiklopedi Fakta Alkitab, Bible Almanac Jilid 2 (Malang: Penerbit Gandum Mas, 2004), p. 1118.
} 
komunitas itu mengembangkan doktrin mereka yang unik sendiri. ${ }^{47}$

Paulus menyebutkan tiga orang meninggalkan iman untuk menganut ajaran sesat ini: Himeneus, Aleksander, dan Filetus (1 Tim. 1:20; 2 Tim. 2:1718). Mereka menyatakanbahwa kebangkitan telah berlangsung, kemungkinan mempercayai bahwa roh apa pun yang "tersisa" ketika seseorang mati akan kembali terserap di dalam Allah. Di Kreta sendiri, Titus juga menghadapi tantangan dari pihak Gnostik, oleh sebab itu ia dinasihatkan untuk dengan tegas memerangi ajaran yang merusakkan iman Kristiani gereja Tuhan di Kreta.

Kelompok ketiga ajaran sesat dalam gereja mula-mula adalah pengeikut Nikolaus. Rasul Yohanes memusatkan perhatian pada paham Gnostik yang lebih ekstreemm yang merajalela di seluruh gereja abad pertama (1 dan 2 Yoh.; Wah. 2:6, 14, 15). Mereka ini adalah pengikut Nikolaus yang sangat berbahaya yang menegaskan bahwa, karena tubuh mereka masih dalam bentuk jasmani (dan karena itu jahat), maka hanya yang dilakukan oleh roh merekalah yang penting. Jadi mereka merasa bebas untuk menuruti kehendak dalam melakukan hubungan seksual secara sembanrangan, untuk memakan makanan yang sudah dipersembahkan kepada berhala dan melakukan apa saja yang mereka senangi dengan tubuh mereka.

Gereja mula-mula bertindak tegas terhadap orang-orang yang menyimpang dari kebenaran Kristus yang mulia. Mereka melarang para penganut bidat mengikuti persekutuan dan berdoa bagi keselamatan mereka. Paulus menegur mereka secara terbuka. Ia merasa bahwa para pengikut bidat harus disingkirkan dari gereja, sebelum mereka menyebarkan ide-ide mereka yang menyebabkan kebinasaan.

Tema kedua dari surat Titus adalah tentang guru-guru palsu ini dan perlunya untuk membantah ajaran palsu ini (Tit. 1:10-16). Di Kreta ternyata sudah terjadi ada banyak orang yang hidupnya tidak tertib, terutama di antara mereka yang berpegang pada hukum sunat dengan omongan mereka yang sia-sia mereka menyesatkan pikiran (Tit. 1:10). Orang-orang semacam itu harus ditutup mulutnya, karena mereka mengacau banyak keluarga dengan mengajarkan yang tidak-tidak untuk mendapat

untung yang memalukan. Orang-orang yang berpegang pada hukum Sunat ini adalah orang-orang Yahudi yang mencoba untuk mempengaruhi jemaat Tuhan supaya mereka kembali kepada hukum Taurat

\footnotetext{
${ }^{47}$ Ibid., p. 1118.
}

dan dengan demikian meninggalkan kasih karunia Allah dalam Yesus Kristus.

Bahkan Paulus mengutip pernyataan seorang dari kalangan orang Kreta sendiri, yaitu: nabi mereka sendiri, pernah berkata: "Dasar orang Kreta pembohong, binatang buas, pelahap yang malas." 48 Paulus menegaskan bahwa kesaksian dari nabi dari Kreta $^{49}$ itu benar. Karena itu Titus disuruh untuk menegor mereka dengan tegas supaya mereka menjadi sehat dalam iman, dan tidak lagi mengindahkan dongeng-dongeng Yahudi dan hukum-hukum manusia yang berpaling dari kebenaran. Bagi orang suci semuanya suci; tetapi bagi orang najis dan bagi orang tidak beriman suatupun tidak ada yang suci, karena baik akal maupun suara hati mereka najis. Mereka mengaku mengenal Allah, tetapi dengan perbuatan mereka, mereka menyangkal Dia. Mereka keji dan durhaka dan tidak sanggup berbuat sesuatu yang baik.

Sifat orang-orang Kreta dipaparkan dengan gamblang dan salah satu ucapan pujangga mereka dikutip untuk mendukung kemerosotan moral dan materialisme mereka. Paulus memakai ungkapan terkeras untuk menyebut mereka (keji, durhaka, tidak sanggup berbuat apa yang baik) dan tidak heran jika Titus didesak untuk menegur mereka. Mereka adalah kelompok orang yang menganut ajaran Gnostik, dimana mereka meyakini bahwa mereka memiliki pengetahuan-pengetahuan rahasia yang tidak dimiliki Paulus, yaitu berkenaan dengan hal-hal materi. Dengan demikian mereka diyakinkan sendiri untuk bebas hidup menuruti segala keinginan daging mereka.

Orang-orang semacam itu harus dibungkam mulutnya. Cara yang baik untuk menghadapi golongan ini adalah dengan tidak memberikan mereka kesempatan untuk berbicara sehingga mereka tidak bisa mempengaruhi jemaat lainnya dengan pemikiran mereka yang menyesatkan.

\footnotetext{
48 Titus $1: 11$

${ }^{49}$ Paulus di sini mengutip sebaris syair dari filsuf Kreta, epimenides yang menulis kira-kira 600 sM. Dalam bahasa yang menarik perhatian, Paulus menyeburknya seorang nabi dan membenarkan kesaksiannya sebagai benar. Hal ini memberi dukungan alkitabiah untuk mempercayai bahwa bangsa-bangsa bukan Kristen mempunyai nabinya juga. Kutipan ini rupanya adalah diketahui umum. Memang orangorang Kreta dijuluki pendusta di dunia Yunani. Sifat ajaran palsu dan para penyebarnya, ditelanjangi secara radikal dan terhukum. D. Guthrie, Tafsiran Alkitab Masa Kini_(Jakarta: BPK Gunung Mulia, 1981) p. 741.
} 
Sudah tentu mereka tidak boleh diberikan tugas mengajar atau mengurus gereja.

Pada jaman dahulu, orang-orang Kreta mempunyai reputasi yang buruk. Paulus mengutip penyair Epimenides, seorang Kreta ${ }^{50}$, yang mungkin telah dikutipnya ketika ia berpidato di Areopagus. Yang dikutip Paulus itu adalah sebuah sajak - "dasar orang Kreta pembohong, binatang buas, pelahap yang malas." Sebenarnya mereka itu adalah sisa suatu bangsa besar yang merosot, yang telah mendirikan peradaban Yunani Minoa 2000 tahun sebelum Kristus. Kenangan rakyat yang samarsamar tentang kekuasaan yang sudah lenyap mungkin sudah merusakkan kekuatan jiwa rakyat jelata di Kreta. Sebuah peribahasa pada zaman Paulus adalah "Kretizein pros Kreta," artinya berbohong kepada seorang pembohong. Epimenides sedang menunjuk kepada pernyataan orang-orang Kreta bahwa di pulau mereka terdapat kubur Zeus ajaran sesat yang sangat melampaui batas. ${ }^{51}$

Jadi, sebagai pemimpin, Titus wajib berdiri teguh melawan sifat-sifat buruk orang Kreta, dan terutama melawan komplotan-komplotan rumah ibadat Yahudi. Banyak surat Paulus ditulis sebagai tanggapan terhadap ancaman-ancaman yang datang dari berbagai lawan: para pengajar kekristenan yang bercorak Yahudi di Galatia, para asketik di Kolose dan para Gnostik Yahudi di Korintus. Timotius dan Titus menghadapi masalah-masalah yang sama, dan sedang di bawah tekanan supaya meninggalkan berita Injil seperti yang disampaikan Paulus kepada mereka.

Ajaran palsu ini terdiri dari berbagai unsur yang telah ditemukan sebelumnya. Hukum Taurat pasti merupakan unsur yang telah ditemukan sebelumnya, sebab beberapa perusuh dikenal sebagai "Orang yang hidup tidak tertib, tetutama di antara mereka yang berpegang pada hukum sunat. Dengan omongan yang sia-sia mereka menyesatkan pikiran" (Tit 1:10). Rupanya orang-orang tersebut memakai Perjanjian Lama bagi kepentingan mereka sendiri. Sebab kepada Timotius Paulus mengingatkan bahwa, "hukum Taurat itu baik kalau tepat digunakan" (1 Tim 1:8). Pandangan-pandangannya khususnya berkisar tentang hubungan seksual dan soal makanan. Ada yang menyatakan bahwa penerangan

\footnotetext{
${ }^{50}$ E.M. Blaiklock, Surat-surat Penggembalan (Malang:

Penerbit Gandum Mas, 1972) p. 72.

${ }^{51}$ Ibid., p. 73.
}

rohani sejati hanya dapat diperoleh melalui kehidupan asketik di mana keberadaan badani material sedapat mungkin disangkal. Tetapi Timotius diajak supaya mengingat, "semua yang diciptakan Allah itu baik dan suatupun tidak ada yang haram" (1 Tim 4:4).

Orang-orang ini kelihatannya condong mengikuti suatu bentuk Gnostisisme Yahudi. Memang secara khusus disebut tentang "omongan yang kosong dan yang tidak suci dan pertentanganpertentangan yang berasal dari apa yang disebut pengetahuan" (gnosis; 1 Tim 6:20). Sama seperti para Gnostik abada kedua, mereka menyangkal bahwa dunia ini benar-benar dunia Allah - sehingga semakin cepat mereka dapat lolos dari dunia, semakin baik keberadaan hidupnya. Kenyataan bahwa lawan-lawan Timotius bertengkar tentang "dongeng dan silsilah yang tiada putus-putusnya, yang hanya menghasilkan persoalan belaka" dan telah "sesat dalam omongan yang sia-sia" (1 Tim 1:4-6) mendukung pandangan tentang orang-orang ini. Tetapi tentunya ada lebih dari satu cara untuk meremehkan keberadaan jasmaniah. Asketisisme bukanlah satu-satunya pilihan: kelonggaran moral secara ekstrim merupakan cara lain. ${ }^{52}$ Dan sedikitnya satu kelompok yang disebutkan di sini rupanya telah memilih alternative tersebut: "Secara lahiriah mereka menjalankan ibadah mereka, tetapi pada kahikatnya mereka memungkiri kekuatannya" (2 Tim 3:5). Bagi Paulus, Injil Kristen selalu menyangkut perubahan gaya hidup, dan bukan bagaimana membangkitkan perdebatan.

Dalam Titus 1:10 dituliskan bahwa guru-guru palsu "tidak tertib", artinya mereka tidak menundukkan pikiran mereka di bawah kebenaran ilahi yang dinyatakan; dan sebagai anggota gereja mereka tidak tertib dan suka memberontak. "Omongan yang sia-sia" mereka mengajarkan halhal yang tidak mempunyai isi atau realita yang sesuai (bandingkan Roma 1:21, 22) dan mempu menyesatkan pikiran orang. Mereka yang merupakan bahaya besar adalah Yahudi dan yang berusaha men-yahudi-kan orang lain, yang menyebarkan ajaran yang berakar dari Yudaisme (bandingkan ayat 14). Oleh karena itu, Titus 1:11 menuliskan bahwa mereka harus dibungkamkan mulutnya, ini berarti mereka tidak boleh diberikan kesempatan untuk berbicara atau megajar di dalam gereja Tuhan. Mereka harus ditegor dengan tegas

\footnotetext{
52 John Drane, Memahami Perjanjian Baru (Jakarta: BPK Gunung Mulia, 2008), p. 395. 
supaya mereka menjadi sehat dalam iman (ayat 13) dan tidak lagi mengindahkan dongeng-dongeng Yahudi dan hukum-hukum manusia yang berpaling dari kebenaran (ayat 14).

Berlawanan dengan Injil dari Allah dan kebenaran, ajaran sesat ini adalah dari manusia dan berisikan dongeng-dongeng atau semata-mata khayalan. Mereka yang mengajarkan itu teah berpaling dari kebenaran. Karena itu memperhatikan ajaran mereka adalah melakukan hal yang sama. Hukum-hukum itu rupannya melarang pemakaian beberapa barang tertentu sebagai haram (Bandingkan 1 Tim. 4:3; Kol. 2:16, 21). Titus 1:15 Paulus menegaskan bahwa bagi orang suci semuanya suci, tetapi bagi orang najis dan bagi orang tidak beriman suatupun tidak ada yang suci, karenna baik akal maupun suara hati mereka najis. "Semuanya" di sini menunjuk pada benda (Bandingkan 1 Tim. 4:4), bukan perbuatan yang pada hakekatnya buruk dari sudut moral. Itu menyatakan, bahwa benda-benda demikian suci atau tidak dalam penggunaannya oleh manusia (bukan dalam pertimbangan mereka) menurut kondisi rohaniah dan moral mereka. Kecemaran muncul dari dalam, bukan dengan perantaraan benda-benda dari luar (Mark. 7:15).

Pengajar-pengajar sesat ini yang mengakui mengenal Allah, tetapi dengan perbuatan mereka, mereka menyangkal Allah. Mereka keji dan durhaka dan tidak sanggup berbuat sesuatu yang baik (Tit. 1:16). Istilah "mengenal" dipakai " oî $\delta \alpha$ yang berarti telah melihat, mengenal. Ini bukan suatu pengenalan yang dalam sehingga mengalami dan memiliki hubungan yang dekat. Ini hanya semacam pengetahuan yang dangkal akan Allah. Kata "perbuatan" dipakai "€́ $ү$ ov (ergon) yang arti dasarnya adalah bekerja, pekerjaan, tingkah laku, perbuatan, usaha, hasil, tugas, apa yang telah dilakukan atau dikerjakan. Dan semua hasil perbuatan yang dinampakkannya terlihat bahwa mereka menyangkal Allah. Tidak sesuai dengan pengakuan mereka bahwa mereka mengenal Allah.

Mereka dikatakan keji dan durhaka dan tidak sanggup berbuat sesuatu yang baik. Istilah "tidak

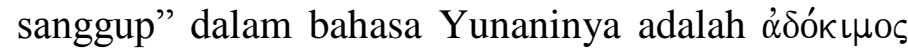
(adokimos) yang artinya "tidak sanggup menghadapi ujian, menolak, tidak lolos kualifikasi, gagal dalam test, tidak terbukti, tidak berharga." ${ }^{33}$ Kehidupan

\footnotetext{
${ }^{53}$ Strong Exhaustive Concordance, p. 96b. Menurut Gingrich

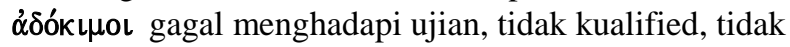

para pengajar palsu tersebut sama sekali tidak sanggup melakukan sesuatu yang baik. Mereka gagal dan tidak berhasil dalam hal-hal yang baik.

\section{Ajaran Mengenai Peraturan bagi Perilaku Kristen(Titus 2:1-10)}

Dalam Titus 2:1 Paulus menuliskan: "Tetapi engkau, beritakanlah apa yang sesuai dengan ajaran yang sehat". Kemudian ayat-ayat selanjutnya berbicara tentang hal-hal apa sajakah yang harus diberitakan sesuai dengan ajaran sehat, yaitu berbagai peraturan bagi perilaku Kristen: 1. dalam hubungan keluarga: a. bagi laki-laki tua (ayat 2), b. bagi perempuan-perempuan yang tua (ayat 3), c. bagi perempuan-perempuan muda (ayat 4-5), d. bagi orang-orang muda (ayat 6); 2. dalam pelayanan (ayat 7-8); 3. dalam hubungan pekerjaan (ayat 910); 4. dalam hubungan dengan pemerintah (Titus $3: 1)$; 5. dalam hubungan dengan semua orang (dunia)Rupanya selama itu telah banyak ajaranajaran yang tidak sehat mempengaruhi hampir seluruh segi kehidupan jemaat Tuhan di Kreta. Itulah sebabnya Paulus merasa perlu untuk memberikan pengajaran yang sehat tentang perilaku Kristen yang benar dalam segala segi kehidupan dan hubungan dalam masyarakat.

Ajaran sehat tentang perilaku dalam kehidupan bersama adalah sebagai berikut. Bagi laki-laki yang tua hendaklah mereka hidup sederhana, terhormat, bijaksana, sehat dalam, dalam kasih dan dalam ketekunan (Tit. 2:2). Bagi perempuan-perempuan yang tua, hendaklah mereka hidup sebagai orang-orang beribadah, jangan memfitnah, jangan menjadi hamba anggur, tetapi cakap mengajarkan hal-hal yang baik dan dengan demikian mendidik perempuan-perempuan muda mengasihi suami dan anak-anaknya, hidup bijaksana dan suci, rajin mengatur rumah tangganya, baik hati dan taat kepada suaminya, agar Firman Allah jangan dihujat orang (Tit. 2:3-4). Dari Titus 2:3-4 terlihat jelas tugas seorang perempuan muda yang menerima teladan dan didikan perempuan tua ialah: mengasihi suami dan anakanaknya, hidup bijaksana dan suci, rajin mengatur rumah tangganya, baik hati dan taat kepada suaminya.

Tujuan dari semua perilaku baik adalah "agar Firman Allah jangan dihujat orang".Titus 2:7 berbicara tentang peraturan hidup bagi orang-orang

berharga (2 Korintus 13:5-7), diskualifikasi (I Korintus 9:27), tidak berharga (Roma 1:28); tidak berguna (Ibrani 6:8), p. 4. 
muda. Dikatakan, "Demikian juga orang-orang muda; nasihatilah mereka supaya mereka menguasai diri dalam segala hal dan jadikanlah dirimu sendiri suatu teladan dalam berbuat baik.

Nasihat untuk Titus sendiri sebagai seorang pelayan Tuhan yang masih muda "jadikanlah dirimu sendiri suatu teladan dalam berbuat baik. Hendaklah engkau jujur dan bersungguh-sungguh dalam pengajaranmu, sehat dan tidak bercela dalam pemberitaanmu sehingga lawan menjadi malu, karena tidak ada hal-hal buruk yang dapat mereka sebarkan tentang kita (Tit. 2:8).

Nasihat dalam hubungan pekerjaan antara hamba dan tuan dalam Titus 2:9 adalah Hambahamba hendaklah taat kepada tuannya dalam segala hal dan berkenan kepada mereka, jangan membantah, jangan curang, tetapi hendaklah selalu tulus dan setia, supaya dengan demikian mereka dalam segala hal memuliakan ajaran Allah, Juruselamat kita.

Alasan untuk hidup benar dan tidak menjadi batu sandungan kepada orang lain, melainkan sebaliknya memuliakan ajaran Allah, Juruselamat orang percaya adalah: Karena kasih karunia Allah yang menyelamatkan semua manusia sudah nyata (Tit. 2:11). Kasih karunia itu mendidik orang-orang percaya (Tit. 2:12) supaya: Orang-orang percaya meninggalkan kefasikan dan keinginan-keinginan duniawi dan supaya mereka hidup bijaksana, adil dan beribadah di dalam dunia sekarang ini. Caranya ialah dengan menantikan penggenapan pengharapan kita yang penuh bahagia dan penyataan kemuliaan Allah yang Mahabesar dan Juruselamat kita Yesus Kristus (Tit. 2:13), yang telah menyerahkan diriNya bagi kita untuk membebaskan kita dari segala kejahatan dan untuk menguduskan bagi diri-Nya suatu umat, kepunyaan-Nya sendiri, yang rajin berbuat baik (Tit. 2:14).

Dalam hubungan dengan pemerintahan, tugas Titus adalah untuk (Tit. 3:1) mengingatkan jemaat Tuhan supaya mereka tunduk pada pemerintah dan orang-orang yang berkuasa, taat dan siap untuk melakukan setiap pekerjaan yang baik. Janganlah mereka memfitnah, janganlah mereka bertengkar, hendaklah mereka selalu ramah dan bersikap lemah lembut terhadap semua orang (ayat 2). Karena dahulu orang-orang percaya juga hidup dalam kejahilan: tidak taat, sesat, menjadi hamba berbagaibagai nafsu dan keinginan, hidup dalam kejahatan dan kedengkian, keji, saling membenci (ayat 3). Jadi tidak ada alasan untuk mereka menghakimi orangorang dunia yang belum bertobat itu, sebaliknya mereka harus menjadi saksi dalam melakukan setiap pekerjaan yang baik.

\section{KESIMPULAN}

Tema teologi Titus adalah "Ajaran Sehat". Hal ini dapat dimengerti melalui arti ungkapan tersebut sesuai dengan konteknya.Selanjutnya ajaran-ajaran teologi mengenai Allah, Yesus Kristus, Roh Kudus, Soteriologi serta Kehidupan Kristen (perbuatan baik) yang merupakan pokokpokok yang diajarkan menunjukkan bahwa inilah yang dimaksud Paulus dengan apa yang disebut "Ajaran Sehat"Penerapan ajaran-ajaran tersebut dalam kelompok-kelompok orang percaya termasuk di alamnya Paulus dan Titus menguatkan memang yang dibicarakan surat Titus adalah "Ajaran Sehat" beserta penerapannya.

\section{KEPUSTAKAAN}

[1] Arndt, William F. dan F. Wilbur Gingrich, " A Greek-English Lexicon of the NewTestament and Other Early Christian Literatus", terjemahan dari Walter"s Bauer. The University of Chicago Press, 1987

[2] Barnett, A. E. Paul Becomes a Literary Influence. 1941.

[3] Bernard, J. H. The Pastoral Epistles. 1899.

[4] Blaiklock, E.M. Surat-surat Penggembalaan (Buku Pedoman untuk Mempelajari Surat-surat Kirimiman I dan II Timotius dan Titus . Malang: Penerbit Gandum Mas, 1972

[5] Campenhausen. H. von. "Polykarp und die Pastoralbriefe," Sitzungsberichte der Heidelberger Akademic der Wissenchaften, philosophisch-historische Klasse 1951.

[6] Conner, Kevin J. Jemaat dalam Perjanjian Baru. Malang: Penerbit Gandum Mas, 2004

[7] Dibelius, The Pastoral Epistles (H. conzelmann, ed.),1972.

[8] Douglas, J. D. Ensiklopedi Alkitab Masa Kini Jilid II. Jakarta: Yayasan Komunikasi Bina Kasih/OMF, 2004.

[9] Drane, John. Memahami Perjanjian Baru. Jakarta: BPK Gunung Mulia, 2008.

[10] Elwell, Wartel A. , Robert W. Yarbrough, Encountering The New Testament. Grand Rapids: Baker Book House Company, 1998.

[11] Falconer, Sir R. Pastoral Epistles. 1937. 
[12] The New Testament in the Apostolic Fathers Oxford Society of Historical Theology. 1905.

[13] Guthrie, Donald. Pengantar Perjanjian Baru Jilid 2. Surabaya: Penerbit Momentum, 2009.

[14] Guthrie, Donald. Tafsiran Alkitab Masa Kini Jilid 3 Jakarta: BPK Gunung Mulia, 1981.

[15] Harnack, A. Die Briefsammlung des Apostels Paulus, 1926.

[16] Harrison, P.N. The Problem of the Pastoral Epistles. 1921.

[17] James, J. D. The Genuineness and Authorship of the Pastoral Epistles. 1906.

[18] Jeremias, Die Briefe an Timotheus, 1807

[19] Merryl C. Tenney, New Testament Survey. Grand Rapids: Wm.B. Publishing Co., 1985

[20] Packer, J.J., dan Merril C. Tenney, dan Willian White Jr. Ensiklopedi Fakta Alkitab, Bible Almanac Jilid 2. Malang: Penerbit Gandum Mas, 2004

[21] Ramsay, W.M. St. Paul The Traveller and Roman Citizen, 1920.

[22] Schleiermarcher, F. Uber den sogenannten ersten Brief des Paulus an den Timotheus, 1807.

[23] Streeter, B.H. The Primitive Church. 1929.

[24] Summer, Ray. Diktat Yang Pokok dalam Bahasa Yunani Perjanjian Baru terjemahan Petrus Maryono (Yogyakarta: STII nd),

[25] Tenney Merryl C., New Testament Survey. Grand Rapids: Wm.B. Publishing Company. 1985.

[26] Vine, W.E. The Expanded Vine's Expository Dictionary of New Testament Words Minneapolis: Bethany House Publishers, 1984

[27] (C1996 David Malick, http://www.bible.org.

[28] C1997, 1998, 1999 Biblical Studies Press cd

[29] usebius, Ecclesiastical History, 3.4.6

[30] Biblical Studies Press Titus cd

[31] PC Study Bible V5. OC for Windows 19882006 Jim Gibertson

[32] Thayer "Greek Lexicon"(C) 1992-2005 BibleWorks, LLC.
[33] Vine's Expository Dictionary of Biblical Words, PC Study Bible V5. OC for Windows 1988-2006 Jim Gibertson 